\title{
Pengaruh Pendidikan Kesehatan Metode Audio Visual terhadap Perilaku Pemeriksaan Inspeksi Visual Asam (IVA), pada Wanita Usia Subur Di Wilayah Puskesmas Bengkulu Tengah Tahun 2020
}

\author{
Warman Alamsyah $^{1^{*}}$, Defriman Djafri ${ }^{2}$, Khairul Andri ${ }^{3}$ \\ ${ }^{1}$ Pasca Sarjana Peminatan Keperawatan Komunitas Universitas Andalas \\ ${ }^{2}$ Fakultas Kesehatan Masyarakat Universitas Andalas \\ ${ }^{3}$ Sekolah Tinggi Ilmu Kesehatan Indonesia Padang \\ *Correspondence email: Alamsyahwarman@gmail.com
}

\begin{abstract}
Abstrak. Kanker Leher rahim (servik) menjadi masalah kesehatan khususnya bagi wanita usia subur yang sudah melakukan hubungan seksual mengakibatkan terjadi hal-hal yang tidak perlu sehingga pemeriksaan IVA menjadi tidak optimal . tujuan penelitian ini yaitu untuk mengetahui pengaruh pendidikan kesehatan metode audivisual terhadap perilaku pemeriksaan Inspeksi Visual Asam (IVA), pada Wanita Usia Subur di wilayah kerja Puskesmas Bengkulu Tengah. Desain penelitian ini yaitu Quasy Experimen Pre-post With Control Group. Jumlah sampel yaitu 60 wanita usia subur (WUS) yang terdiri dari 30 wanita usia subur (WUS) kelompok intervensi dan 30 wanita usia subur (WUS) kelompok kontrol. Teknik dalam pengambilan sampel menggunakan total sampeling. Data dianalisis menggunakan uji Independen Samples T-test. Hasil penelitian menunjukkan bahwa adanya pengaruh signifikan terhadap pengetahuan (nilai $p$ value $=0,006$ ), sikap (nilai $p$ value $=0,000$ ) dan perilaku pemeriksaan (nilai $p$ value $=0,004$ ). Kesimpulan pendidikan kesehatan metode audiovisual ini efektif dalam memperbaikai pengetahuan, sikap dan perilaku pemeriksaan Inspeksi Visual Asam (IVA), pada Wanita Usia Subur. Saran pendidikan kesehatan metode audiovisual dapat digunakan puskesmas sebagai inovasi dalam menyampaikan informasi Khususnya bagi pengelola program PTM dan posbindu.
\end{abstract}

Kata kunci: Pendidikan kesehatan metode audiovisual; WUS; pengetahuan; sikap; perilaku

\begin{abstract}
Cervical cancer (cervical) becomes a health problem especially for women of childbearing age who have had sexual intercourse resulting in unnecessary things so that IVA examination is not optimal. the purpose of this study was to determine the effect of audivisual methods of health education on the behavior of the Visual Acid Inspection (IVA), in Fertile Women in the Public health center working area. The design of this study is the Quasy Experiment Pre-post With Control Group. The number of samples is 60 women of childbearing age (WUS) consisting of 30 women of childbearing age (WUS) intervention group and 30 women of childbearing age (WUS) control group. The technique in sampling uses total sampling. Data were analyzed using the Independent Samples T-test. The results showed that there was a significant influence on knowledge $(p$ value $=0.006)$, attitudes ( $p$ value $=0,000)$ and inspection behavior ( $p$ value $=0.004)$. Conclusion This audiovisual method of health education is effective in improving the knowledge, attitudes and behavioral examination of Visual Acid Inspection (IVA), in Fertile Women. The audiovisual method of health education can be used by the Public health center as an innovation in conveying information, especially for PTM and Posbindu program managers
\end{abstract}

Keywords: Health education; audiovisual methods; WUS; knowledge; attitudes; behavior

\section{PENDAHULUAN}

Pembangunan kesehatan sebagai salah satu upaya pembangunan nasional diarahkan guna tercapainya kesadaran, kemauan, dan kemampuan untuk hidup sehat bagi setiap penduduk agar dapat mewujudkan derajat kesehatan yang optimal. Kesehatan yang demikian yang menjadi dambaan setiap orang sepanjang hidupnya. Tetapi datangnya penyakit merupakan hal yang tidak bisa ditolak meskipun kadang-kadang bisa dicegah atau dihindari (Kessler, 2017).

Kanker serviks adalah kanker yang mengenai leher rahim (serviks). Kanker secara umum merupakan sel-sel yang mengalami pembelahan diri secara tidak terkendali. Pada wanita kanker yang paling mematikan nomor 1 saat ini adalah kanker serviks atau kanker mulut rahim (Kumalasari, 2016). Angka prevalensi kejadian kanker di dunia masih menduduki peringkat tertinggi setelah penyakit kardiovaskular dan menjadi penyebab utama kematian (Kessler, 2017).

Badan Organisasi Kesehatan Dunia/World Health Organization (WHO) mengungkapkan, angka kesakitan akibat kanker di dunia pada tahun 2012 sekitar 14,1 juta dengan angka kematian 8,2 juta. kanker Servik ini masih banyak ditemukan di negara berkembang termasuk Indonesia. Insiden kanker serviks diambil dari Global Burden Cancer (Globocan), International Agency For Research On Cancer (IARC) tahun 2012 sebesar 16 per 100.000 penduduk. dimana kanker leher rahim ini terus meningkat diseluruh dunia, diperkirakan akan mencapai 10 juta kasus baru setiap tahun dan pada tahun 2020 diperkiran akan mencapai 15 juta kasus. Sedangkan Data lainnya, Globocan tahun 2018 menunjukkan kejadian penyakit kanker pada perempuan, kasus tertinggi adalah kanker payudara sebesar 42,1 per 100.000 penduduk 
Warman Alamsyah et al, Pengaruh Pendidikan Kesehatan Metode Audio Visual terhadap Perilaku Pemeriksaan Inspeksi Visual Asam (IVA), pada Wanita Usia Subur Di Wilayah Puskesmas Bengkulu Tengah Tahun 2020

dengan rata-rata kematian 17 per 100.000 . Setelah itu kanker leher rahim sebesar 23,4 per 100.000 penduduk dengan rata-rata kematian 13,9 per 100.000 penduduk. (Bray et al., 2018).

Indonesia sendiri angka kejadian kanker masih dibilang cukup tinggi, berdasarkan Riset Kesehatan Dasar (Riskesdas) yang dilakukan pada tahun 2013 menyebutkan bahwa angka kejadian tumor maupun kanker di Indonesia sendiri mencapai 1,4 per 1000 penduduk (sekitar 330.000 orang) (Riskesdas, 2013). Sedangkan, pada tahun 2018 jumlah penderita kanker meningkat menjadi 347.792 orang. Jumlah kanker serviks terbanyak berada di Provinsi Jawa timur yaitu sebanyak 21.313 kasus kanker serviks, Jawa Tengah sebanyak 19.734 kasus kanker serviks, Jawa Barat 15.635 kasus kanker serviks. Sedangkan di Provinsi Bengkulu jumlah kanker serviks sebanyak 705 kasus kanker serviks (Menteri Kesehatan R.I, 2018)

Meningkatnya jumlah kasus baru kanker serviks di Indonesia pada setiap tahunnya ini dapat menjadi ancaman besar bagi dunia kesehatan, karena mayoritas penderitanya baru terdeteksi dan datang pada stadium lanjut. Padahal kanker serviks dapat dicegah dan terdeteksi lebih awal jika wanita usia subur mempunyai pengetahuan yang baik dan kesadaran melakukan deteksi dini (Sulistiowati \& Sirait, 2014).

Program pencegahan kanker servik selain deteksi dini faktor resiko dapat dilakukan pencegahan yaitu melalui pendidikan kesehatan tentang deteksi dini kanker mulut rahim sehingga masyarakat bisa tergerak untuk segera melakukan pemeriksaan dengan metode yang paling mudah, murah dan terjangkau yaitu melalui pemeriksaan Metode IVA test, dengan memberikan informasi melalui pendidikan kesehatan yang dapat meningkatkan pengetahuan masyarakat tentang perilaku sehat (Bradley, 2018).

Pendidikan kesehatan dapat menggunakan berbagai media, salah satunya adalah Pendikan kesehatan metode audiovisual untuk memberikan stimulus pada pendengaran dan penglihatan sehingga hasil yang diperoleh bisa maksimal (Maulana, 2009).

Dinas kesehatan Propinsi Bengkulu tahun 2015, dari 10 kabupaten kota cakupan deteksi dini kanker leher rahim dengan metode IVA, pada WUS umur 30-50 tahun berjumlah 267.779 orang, dan yang melakukan pemeriksaan IVA berjumlah 2.529 orang,dengan IVA positif $127(5,02 \%)$, pemeriksaan dengan metode IVA positif, yang paling tingi terdapat pada Kabupaten Bengkulu tengah, terdapat 71 orang $(17,36 \%)$, dan Kabupaten Rejang lebong terdapat 22 (5,08\%) (Dinkes Provinsi Bengkulu, 2015).

Kabupeten Bengkulu Tengah merupakan pemekaran pada tahun 2011. Dari Kabupaten Bengkulu utara, wawancara dengan kepala dinas kesehatan, fenomena kanker servik didapatkan data WUS memiliki insiden tertinggi pada dua puskesmas yaitu, puskesmas Taba Lagan, dan Puskesmas Kembang Seri, dengan sasaran WUS 3.589 jiwa. Tentunya dalam hal ini dinas kesehatan selalu meningkatkan sarana prasarana kesehatan seperti akses jalan, sumber daya manusia (SDM) dan memberikan pelatihan kepada tenaga kesehatan pada tahun 2016 untuk deteksi dini kanker servik dengan metode IVA didua puskesmas tersebut. Bahwa faktor yang jadi penghambat WUS, alasan seorang wanita tidak menjalani deteksi dini kanker serviks yaitu karena ketidaktahuan, rasa malu, rasa takut dan faktor biaya. Hal ini umumnya disebabkan oleh rendahnya tingkat pendidikan dan pengetahuan penduduk Indonesia, khususnya kaum wanita. Pengetahuan atau kognitif merupakan domain yang sangat penting untuk terbentuknya tindakan seseorang untuk melakukan pemeriksaan, masih banyak yang belum memahami tentang pentingnya pemeriksaan IVA ini, sehingga menimbulkan rasa takut, cemas , malu, dan ada yang mengatakan terasa sakit. Tahapan awal terlaksananya program IVA sosialisasi sudah disampaikan kepada masyarakat, namun belum pernah dilakukan pendidikan kesehatan dengan metode audiovisual.

Partisipasi dari warga di desa pada kedua Puskesmas tersebut terbilang masih rendah, hal ini berdasarkan data yang ada di dua Puskesmas bahwa dari bulan Januari hingga November 2019 belum ada warga yang melakukan pemeriksaan IVA di Puskesmas tersebut. Pendidikan kesehatan yang pernah dilaksanakan di Taba Lagan, dan Puskesmas Kembang Seri adalah pendidikan kesehatan IVA melalui metode ceramah biasa, sehingga banyak dari pasien yang kurang memperhatian dikarenakan kurang menarik selain itu banyak dari pasien yang di undang untuk penyuluhan kesehatan mengenai IVA diantaranya lebih banyak mengobrol dengan sesama pasien yang lain dan ada yang tertidur dan bermain handphone, oleh karena itu untuk meningkatkan partisipasi pasien mengenai pendidikan kesehatan IVA perlunya metode lain, seperti metode audiovisual yang berisikan gambar yang membuat mereka lebih tertarik untuk datang dan lebih mendengarkan apa yang disampaikan petugas kesehatan.

Selain itu, survey awal dengan 6 orang WUS di bengkulu tengah di didapatkan diantaranya tidak tau pemeriksaan IVA, 1 orang mengatakan mengetahui namun tidak tahu penjabarannya, dan untuk 2 orang lagi mengatakan tahu mengenai deteksi dini kanker serviks namun tidak tahu dimana harus memeriksakannya. Wawancara peneliti dengan salah satu petugas kesehatan di tiga Puskesmas tersebut, didapatkan bahwa kunjungan WUS untuk pemeriksaan IVA masih rendah, salah satu penyebabnya yaitu kurangnya sosialisasi disinilah pentingnya peran tenaga kesehatan untuk melakukan pendidikan kesehatan terkait pemeriksaan IVA untuk deteksi dini kanker serviks kepada masyarakat. 


\section{METODE}

Jenis penelitian ini adalah deskriptif dengan pendekatan quasi ekperimen rancangan Pre test dan Post test With control group. Subjek penelitian adalah Wanita Usia Subur (WUS) usia 15-35 tahun dan bertempat di wilayah kerja Puskesmas kabupaten Bengkulu Tengah yang memenuhi kriteria inklusi sebanyak 60 orang yang terbagi menjadi 30 kelompok kontrol dan 30 kelompok intervensi. Penelitian dilakukan Puskesmas taba lagan sedangkan kelompok kontrol di kembang seri, Kabupaten bengkulu Tengah. Data dikumpulkan dengan menggunakan kusioner. Analisis data dilakukan menggunakan software SPSS.

\section{HASIL PENELITIAN \\ Karakteristik responden}

Tabel 1. Karakteristik responden

\begin{tabular}{lllll}
\hline \multirow{2}{*}{ Karakteristik Responden } & \multicolumn{2}{c}{$\begin{array}{c}\text { Kelompok } \\
\text { Kontrol }\end{array}$} & \multicolumn{2}{c}{$\begin{array}{c}\text { Kelompok } \\
\text { Intervensi }\end{array}$} \\
\cline { 2 - 3 } & $\mathrm{N}$ & $\%$ & $\mathrm{~N}$ & $\%$ \\
\hline Umur & 20 & 66.7 & 17 & 56.7 \\
Dewasa awal (26-35) & 10 & 33.3 & 13 & 43.3 \\
Dewasa akhir (36-45) & & & & \\
Pendidikan & 2 & 6.7 & 7 & 23.3 \\
SMP & 21 & 70 & 17 & 56.7 \\
SMA & 7 & 23.3 & 6 & 20.0 \\
PT & & & & \\
Pekerjaan & 2 & 6.7 & 1 & 3.3 \\
PNS & 25 & 83.3 & 29 & 96,7 \\
IRT & 3 & 10 & 0 & 0 \\
WIRASWASTA & & & & \\
Jumlah anak & 3 & 10 & 6 & 20 \\
1 & 15 & 50 & 14 & 46.7 \\
2 & 5 & 16.7 & 7 & 23.3 \\
3 & 5 & 16.7 & 3 & 10 \\
4 & 2 & 6.7 & 0 & 0 \\
\hline
\end{tabular}

Sumber: Data diolah

Berdasarkan tabel 1 di atas menunjukan karakteristik responden kelompok intevensi 17 orang (56.7\%) berusia dewasa awal 26-35 tahun, 17 orang (56.7\%) berpendidikan SMA, dan 29 orang (96.7\%) IRT, 14 orang (46\%) yang mempunyai dua anak. Karakteristik pada kelompok kontrol 20 orang $(66.7 \%)$ berusia dewasa awal 26-35 tahun, 21 orang (70\%) berpendidikan SMA, dan 25 orang (83.3\%) IRT, 15 orang (50\%) punya 2 anak.

Tabel 2. Pengetahuan

\begin{tabular}{lllll}
\hline Kelompok & Pengetahuan & N & SD & P Value \\
\hline Intervesni & Pre Test & 30 & 1,634 & \multirow{2}{*}{0.000} \\
& Post Test & 30 & 1,852 & \\
Kontrol & Pre Test & 30 & 2,297 & 0.889 \\
& Post Test & 30 & 1.826 & \\
\hline
\end{tabular}

Sumber: Data diolah
Berdasarkan tabel 2 analisis pada kelompok intervensi dengan uji paired sampel t test adalah 0.000 ( nilai $\mathrm{p}$ value $<0,05)$ artinya ada perbedaan nilai pengetahuan pre test dan post test pada kelompok intervensi. Sedangkan pada kelompok kontrol dengan Uji paired sample $t$ yaitu 0.889 (nilai $\mathrm{p}$ value $>0,05$ ) artinya tidak ada perbeaan niai pengetahuan pre test dan post test pada kelompok control

\begin{tabular}{lllll}
\multicolumn{5}{c}{ Tabel 3. Sikap } \\
\hline Kelompok & Sikap & N & SD & P Value \\
\hline Intervesni & Pre Test & 30 & 3.605 & \multirow{2}{*}{ To,000 } \\
& Post Test & 30 & 6.073 & \\
& Pre Test & 30 & 6,765 & 0,508 \\
& Post Test & 30 & 1,906 & \\
\hline
\end{tabular}

Sumber: Data diolah

Berdasarkan tabel 3 analisis pada kelompok intervensi dengan uji paired sampel t test adalah 0.000 ( nilai $\mathrm{p}$ value $<0,05$ ) artinya ada perbedaan nilai sikap pre test dan post test pada kelompok intervensi. Sedangkan Analisi pada kelompok kontrol dengan Uji paired sample $t$ yaitu 0.508 (nilai $\mathrm{p}$ value $>0,05$ ) artinya tidak ada perbeaan niai sikap pre test dan post test paa kelompok kontrol

Tabel 4. Perilaku

\begin{tabular}{|c|c|c|c|c|}
\hline kelompok & $\begin{array}{l}\text { Perilaku } \\
\text { pemeriksaan }\end{array}$ & $\mathbf{N}$ & SD & P Value \\
\hline Intervesni & Pre Test & 30 & 1,406 & 0,000 \\
\hline Kontrol & $\begin{array}{l}\text { Post Test } \\
\text { Pre Test }\end{array}$ & $\begin{array}{l}30 \\
30\end{array}$ & $\begin{array}{l}1,570 \\
1,929 \\
1821\end{array}$ & 0,476 \\
\hline & Post Test & 30 & 1,821 & \\
\hline
\end{tabular}

Sumber: Data diolah

Berdasarkan tabel 4 analisis pada kelompok intervensi dengan uji paired sampel t test adalah 0.000 ( nilai $\mathrm{p}$ value $<0,05)$ artinya ada perbedaan nilai perilaku pemeriksaan pre test dan post test pada kelompok intervensi. Sedangkan pada kelompok kontrol dengan Uji paired sample $t$ yaitu 0.476 (nilai $\mathrm{p}$ value $>0,05$ ) artinya tidak ada perbedaan nilai perilaku pemeriksaan pre test dan post test pada kelompok kontrol.

\section{Pembahasan}

Terdapatnya Peningkatan dan perbedaan pada nilai rata-rata pengetahuan menurut peneliti dikarenakan dikelompok intervensi diberikan pendidikan kesehatan media audiovisual dengan video sedangkan pada kelompok kontrol tanpa perlakuan sama sekali. Hal ini menunjukan bahwa pendidikan kesehatan dapat meningkatkan pengetahuan pada wanita usia subur terkait masalah pencegahan kanker servik dengan metode iva. Peningkatan pengetahuan merupakan faktor pendukung terbentuknya sikap yang positif sekaligus perubahan perilaku terhadap pencegahan kanker servik, oleh karena itu pentingnya pengetahuan yang luas dalam memhami penyakit Vidiyanti, (2015). 
Warman Alamsyah et al, Pengaruh Pendidikan Kesehatan Metode Audio Visual terhadap Perilaku Pemeriksaan Inspeksi Visual Asam (IVA), pada Wanita Usia Subur Di Wilayah Puskesmas Bengkulu Tengah Tahun 2020

Pemberian informasi secara faktual dengan menggunakan metode audiovisual menurut Ega,(2015) merupakan media yang dapat menampilkan unsur gambar dan suara secara bersamaan pada saat berkomunikasi dengan pesan atau informasi sehingga dapat mengungkapkan suatu peristiwa dan objek dengan keadaan yang sebenarnnya. Pendidikan kesehatan metode audivisual ini lebih menarik dan dapat dimengerti. Hal ini sesuai dengan penelitian Endah Sri dkk, (2016) bahwa terdapat pengaruh pendidikan kesehatan dengan metodde audiovisual terhadap pengetahuan Wuss tentang kanker servik dengan $p$ value < (0. 05). Penelitian Ni Putu dkk, (2018) bahwa pendidikan kesehatan dengan media audio visual sangat berpengaruh terhadap pengetahuan WUS tentang kanker serviks dan berhubungan dengan motivasi untuk melaksanakan deteksi dini melalui IVA test dengan $\mathrm{p}$ value $<0.001$.

Peneliti melakukan evaluasi terkait dengan peningkatan pengetahuan tentang kanker servik dan cara pencegahannya dimana responden mengatakan bahwa pengetahuan bertambah setelah mengikuti pendidikan kesehatan dengan metode audiovisual melalui penayangan video. Juga pemegang program IVA mengatakan media sangat menarik dan akan diterapkan pada puskesmas dalam rangka peningkatan pengetahuan wanita usia subur.

Temuan dari peneliti, teori dan penelitian sebelumnya, maka peneliti berharap kepada pihak puskesmas untuk dapat melakukan pendidikan kesehatan dengan metode audiovisual dengan penayangan video. Mengingat perlakuan pada kelompok intervensi memberikan hasil yang efekftif dalam peningkatan pengetahuan tentang masalah bahaya kanker servik dan cara pencegahannya, sehingga metode ini dapat dijadikan alternatif dalam berbagi informasi.

Pemberian intervensi dengan metode audiovisual dapat meningkatkan sikap pada wanita usia subur. Penelitian dilakukan Sri Mulyati, dkk. (2015) didapatkan $(\mathrm{p}<0.05)$ dengan peningkatan medean (rentang) skor sikap dari 44.23(19.23-75) menjadi 78.85(25-94-23) sehingga terdapat pengaruh positif pendidikan kesehatan melalui media video terhadap sikap ibu. Penelitian(Mutoharoh, 2019) dengan hasil pre test yaitu dengan nilai cukup ( $56.5 \%$ ) dan baik (43.5\%) sedangkan pada pos Test dengan nilai yaitu baik (87\%) dan cukup (13\%) berarti menunjukan adanya peningkatan sikap WUS setelah dilakukan intervensi

Selain itu hasil analisis juga diketahui adanya perbedaan peningkatan nilai rata-rata sikap antara kelompok intervensi dan kelompok kontrol didapatkan perbedaan 8.44 sedangkan pada kelompok kontrol didapatkan perbedaan 0.23 . hal ini juga menunjukkan bahwa perbedaan yang didapatkan pada kelompok intervensi lebih tinggi dibandingkan dengan perbedaan pada kelompok kontrol.
(Notoatmojo, 2010) Sikap sesorang tidak otomatis terwujud dalam tindakan nyata, Sikap juga akan di ikuti atau tidak berdasarkan pengalaman yang dimiliki responden. Karena seringkali tejadi bahwa seseorang memperlihatkan tindakan yang bertentangan dengan sikapnya. Responden yang memiliki sikap baik terhadap tindakan pencegahan kanker leher rahim dengan metode iva belum tentu akan melakukan pemeriksaan Dewi dkk, (2010).

Berdasarkan hasil penelitian, peneliti melakukan evaluasi terkait peningkatan sikap responden terhadap dalam pencegahan kanker servik. dalam hal ini untuk perlu ada adanya dukungan dari pihak tenaga kesehatan itu sendiri seperti ketersediaan fasilitas kesehatan, baik sikap maupun perilaku dari tenaga kesehatan, faktor yang mempegaruhi sikap sesorang adalah pengaruh orang lain sangatlah penting dalam memberikan pendidikan kesehatan.

Berdasarkan temuan peneliti, teori dan penelitian sebelumnya, maka peneliti mengharapkan kepada pihak puskesmas untuk lebih terus mengajak dan memberikan sikap dan perilaku terhadap responden bahwa puskesmas akan membuat jadwal untuk melakukan pemeriksaan IVA setiap bulan dan akan dilakukan oleh bidan yang terlatih dan mempunyai sertifikasi untuk melakukan pemeriksaan IVA.

Terdapatnya peningkatan perilaku serta perbedaan nilai rata-rata perilaku menurut peneliti dikarenakan kelompok intervensi diberikan perlakuan dengan penayangan media video sedangkan pada kelompok kontrol tidak ada perlakuan sama sekali. Hal ini menujukkan bahwa pendidikan kesehatan dengan media video dapat meningkatkan perilaku Wus dalam pencegahan kanker servik dengan metode IVA

Sebagain besar responden kelompok intervensi dan kelompok kontrol masih berumur dewasa awal dan pendidikan SMA, dan sebagai ibu rumah tangga. Walau pun dipuskesmas sudah menyediakan fasilitas pemeriksaan IVA, namun pihak puskesmas belum melakukan sosialisasi secara maksimal dan untuk pemberian penyuluhan dengan media video belum pernah sama sekali sehingga masih rendah nya tingkat pemeriksaan iva dan masih memiliki persepsi bahwa pemeriksaan iva belum terlalu penting karena menurut responden tidak ada gejala dan tanda-tanda penyakit kanker servik. sehingga masih tingginya minat dari responen untuk tidak melakukan pemeriksaan pada puskesmas taba lagan dan kembang seri, sesuai dengan penelitian Yuliwati dkk,(2012) mengatakan sebagian besar wus diwilayah puskesmas prambun mempunyai perilaku yang kurang dalam melakukan deteksi dini kanker leher rahim dengan metode iva.

Peneliti melakukan evaluasi dengan menanyakan kepada responden dimana responden mengatakan perlu ada informasi yang sangat bermanfaat untuk mencegah kanker leher rahim dengan selalu memberikan suport pada responden seperti pemeriksaan dirumah maupun 
diposbindu dengan cara memanfaatkan tenaga kader dalam mengajak wus, sehingga wus tidak perlu jauhjauh kepuskesmas dengan kata lain bahwa tenaga kesehatan memang benar-benar mensuport ibu-ibu dalam pencegahan kanker servik.

Dari hasil yang ditemukan peneliti, teori serta penelitian sebelumnya peneliti berharap puskesmas dapat membuat jadwal atau membuat grup whatsap kepada kader untuk program pemeriksaan deteksi dini kanker servik dengan metode iva ini dirumah kader atau pokesdes.

\section{SIMPULAN}

Berdasarkan dari hasil penelitian, peneliti memperoleh kesimpulan bahwa Karakteristik responden kelomopok intervensi dan kontrol seluruhnya berjenis kelamin perempuan, sebagaian besar berusia dewasa awal 26-35 tahun dan sebagian besar berpendidikan SMA, dan sebagian besar sebagai ibu rumah tangga (IRT). Terdapat pengaruh pendidikan kesehatan metode audiovisual pada wanita usia subur dalam peningkatan pengetahuan, sikap dan perilaku sadari pada Wanita Usia Subur.

\section{DAFTAR PUSTAKA}

Bradley, P. (2018). World Cancer Day 2018. British Journal of Healthcare Assistants. https://doi.org/10.12968/bjha.2018.12.2.58

Bray, F., Ferlay, J., \& Soerjomataram, I. (2018). Global Cancer Statistics 2018: GLOBOCAN Estimates of Incidence and Mortality Worldwide for 36 Cancers in 185 Countries. 394-424. https://doi.org/10.3322/caac.21492

Dinkes Provinsi bengkulu. (2015). Profil Kesehatan Provinsi Bengkulu Tahun 2015. Profil Kesehatan Provinsi Bengkulu Tahun 2015.

Kessler, T. A. (2017). Cervical Cancer: Prevention and Early Detection. Seminars in Oncology Nursing, $33(2)$,

172-183. https://doi.org/10.1016/j.soncn.2017.02.005

Kumalasari, D. (2016). Hubungan Pengetahuan dan Sikap dengan Perilaku Seksual Pada Siswa SMK. Jurnal Aisyah: Jurnal Ilmu Kesehatan. https://doi.org/10.30604/jika.v1i1.13

Menteri Kesehatan R.I. (2018). Aakreditasi Puskesmas. Kemenkes R.i.

Mutoharoh, S. (2019). Sikap pada Deteksi Dini Cancer Serviks Wanita Usia Subur melalui Penyuluhan Audiovisual di Kruwed Selokerto Sempor Kebumen. 897-900.

Ratna dkk. (2018). Artikel Penelitian MINAT UNTUK MELAKUKAN DETEKSI DINI KANKER SERVIKS BERDASARKAN PENDIDIKAN DAN PARITAS.

Sulistiowati, E., \& Sirait, A. M. (2014). PENGETAHUAN TENTANG FAKTOR RISIKO, PERILAKU DAN DETEKSI DINI

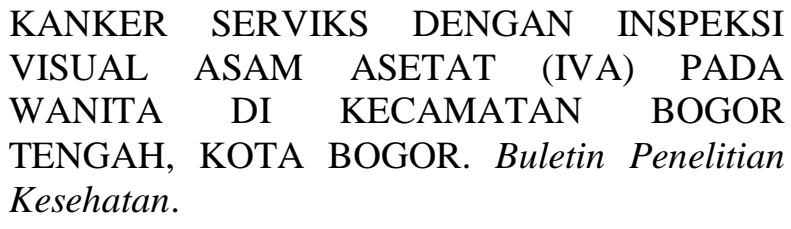

